\title{
Dolabellane Diterpene and Three Cycloartane Glycosides from Thalictrum squarrosum
}

\author{
Hitoshi Yoshimitsu, ${ }^{*}, a$ Hiroyuki Miyashita, ${ }^{a}$ Makiko Nishida, ${ }^{b}$ Tomoko Mineno, ${ }^{c}$ and \\ Toshihiro NOHARA ${ }^{a}$ \\ ${ }^{a}$ Faculty of Pharmaceutical Sciences, Sojo University; 4-22-1 Ikeda, Kumamoto 862-0082, Japan: ${ }^{b}$ Faculty of Home \\ Economics, Kyushu Women's University; 1-1 Jiyugaoka, Yahatanishi-ku, Kitakyushu 807-8586, Japan: and ${ }^{c}$ Faculty of \\ Pharmacy, Takasaki University of Health and Welfare; 60 Nakaorui, Takasaki, Gunma 370-0033, Japan. \\ Received March 17, 2010; accepted May 1, 2010; published online May 13, 2010
}

\begin{abstract}
A new dolabellane diterpene glycoside, named squoside A, and three new cycloartane glycosides, named squarrosides V, VI, and VII, have been isolated from the dried aerial parts of Thalictrum squarrosum (Ranunculaceae). Their structures were determined by two dimensional (2D) NMR spectroscopic analysis and chemical evidence.
\end{abstract}

Key words Thalictrum squarrosum; dolabellane diterpene glycoside; squoside; cycloartane glycoside; squarroside; Ranunculaceae

Thalictrum squarrosum STEPH. is a ranunculaceous plant distributed from the northern area of China to east Siberia. Its dried whole plant has been used as an antacid in traditional Chinese medicine. Previously, we have reported on the isolation and structural elucidation of four triterpene glycosides, squarrosides I, II, III, and IV from the aerial parts of $T$. squarrosum. ${ }^{1)}$ In a continuation of our study on the same plant, we have now isolated a new dolabellane diterpene glycoside, squoside A (1), and three new cycloartane glycosides, squarrosides V (2), VI (3), and VII (4). In this paper, we describe the isolation and structural elucidation based on $2 \mathrm{D}$ NMR spectroscopic analysis and hydrolysis.

\section{Results and Discussion}

The methanolic extract of the dried aerial parts of $T$. squarrosum was partitioned into a benzene-water solvent system. The water-soluble portion was subjected to MCI gel CHP20P, Sephadex-LH20, octadecyl silica gel (ODS), and silica gel column chromatographies and finally HPLC to give squoside A (1) and squarrosides V (2), VI (3), and VII (4).

Squoside A (1) was obtained as an amorphous powder. The molecular formula of $\mathbf{1}, \mathrm{C}_{31} \mathrm{H}_{50} \mathrm{O}_{11}$, was established by the high-resolution (HR)-electrospray ionization (ESI)MS $\left[m / z\right.$ 621.3238, $\left.(\mathrm{M}+\mathrm{Na})^{+}\right]$. The ${ }^{1} \mathrm{H}-$ and ${ }^{13} \mathrm{C}-\mathrm{NMR}$ (methanol- $d_{4}$ ) spectrum revealed 31 carbon signals due to four quaternary methyls $\left[\delta_{\mathrm{C}} 11.6 ; \delta_{\mathrm{H}} 1.57, \delta_{\mathrm{C}} 18.6 ; \delta_{\mathrm{H}} 1.29\right.$, $\delta_{\mathrm{C}} 21.7 ; \delta_{\mathrm{H}} 1.27$, and $\left.\delta_{\mathrm{C}} 24.8 ; \delta_{\mathrm{H}} 1.72\right]$, a secondary methyl $\left[\delta_{\mathrm{C}} 18.9 ; \delta_{\mathrm{H}} 1.30(\mathrm{~d}, J=6.3 \mathrm{~Hz})\right]$, six methylenes $\left[\delta_{\mathrm{C}} 25.4\right.$; $\delta_{\mathrm{H}} 2.16$ and $2.43, \delta_{\mathrm{C}} 28.7 ; \delta_{\mathrm{H}} 1.55$ and $1.77, \delta_{\mathrm{C}} 32.3 ; \delta_{\mathrm{H}}$ 1.37 and $1.58, \delta_{\mathrm{C}} 39.1 ; \delta_{\mathrm{H}} 1.39$ and $1.83, \delta_{\mathrm{C}} 40.6 ; \delta_{\mathrm{H}} 1.25$

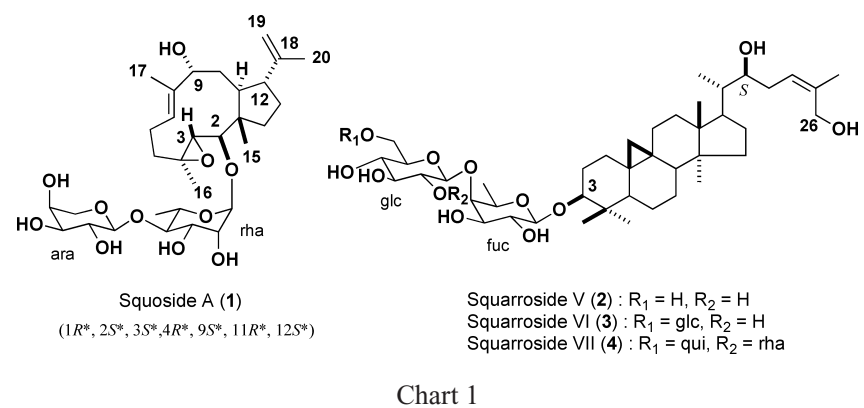

and 2.11 , and $\delta_{\mathrm{C}} 113.1 ; \delta_{\mathrm{H}} 4.71$ and 4.92$]$, an oxygen-bearing methylene $\left[\delta_{\mathrm{C}} 68.3 ; \delta_{\mathrm{H}} 3.54\right.$ and 3.88$]$, three methines $\left[\delta_{\mathrm{C}} 43.2 ; \delta_{\mathrm{H}} 1.65, \delta_{\mathrm{C}} 53.6 ; \delta_{\mathrm{H}} 2.56\right.$, and $\left.\delta_{\mathrm{C}} 129.5 ; \delta_{\mathrm{H}} 5.25\right]$, ten oxygen-bearing methines $\left[\delta_{\mathrm{C}} 68.4 ; \delta_{\mathrm{H}} 2.88, \delta_{\mathrm{C}} 69.7 ; \delta_{\mathrm{H}}\right.$ $3.89, \delta_{\mathrm{C}} 70.8 ; \delta_{\mathrm{H}} 3.79, \delta_{\mathrm{C}} 72.9 ; \delta_{\mathrm{H}} 3.90, \delta_{\mathrm{C}} 73.4 ; \delta_{\mathrm{H}} 3.92$, $\delta_{\mathrm{C}} 74.4 ; \delta_{\mathrm{H}} 3.57, \delta_{\mathrm{C}} 75.4 ; \delta_{\mathrm{H}} 3.52, \delta_{\mathrm{C}} 79.0 ; \delta_{\mathrm{H}} 4.42, \delta_{\mathrm{C}}$ $84.6 ; \delta_{\mathrm{H}} 3.55$, and $\left.\delta_{\mathrm{C}} 87.5 ; \delta_{\mathrm{H}} 3.12\right]$, two acetal methines [ $\delta_{\mathrm{C}}$ $104.2 ; \delta_{\mathrm{H}} 4.76(\mathrm{brs})$ and $\left.\delta_{\mathrm{C}} 107.4 ; \delta_{\mathrm{H}} 4.48(\mathrm{~d}, J=7.5 \mathrm{~Hz})\right]$, three quaternary carbons $\left[\delta_{\mathrm{C}} 51.7,138.3\right.$, and 147.3$]$, and an oxygen-bearing quaternary carbon $\left[\begin{array}{ll}\delta_{\mathrm{C}} & 64.3\end{array}\right]$ (Table 1). The structural assignment was achieved by the ${ }^{1} \mathrm{H}-{ }^{1} \mathrm{H}$ correlation spectroscopy (COSY), total correlation spectroscopy (TOCSY), heteronuclear multiple quantum coherence (HMQC), and heteronuclear multiple bond connectivity (HMBC) experiments. The acid hydrolysis of 1 with $2.0 \mathrm{M}$ hydrochloric acid afforded L-rhamnose and L-arabinose, the structure of which was confirmed by the ${ }^{1} \mathrm{H}-\mathrm{NMR}$ coupling pattern and optical rotation using chiral detection in the HPLC analysis. The aglycon decomposed under an acid condition.

Five partial structures A (2-C-3-C), B (5-C-7-C), C (9$\mathrm{C}-14-\mathrm{C}), \mathrm{D}\left(1^{\prime}-\mathrm{C}-6^{\prime}-\mathrm{C}\right)$, and $\mathrm{E}\left(1^{\prime \prime}-\mathrm{C}-5^{\prime \prime}-\mathrm{C}\right)$ were deduced from detailed analyses of $2 \mathrm{D}$ NMR data $\left({ }^{1} \mathrm{H}-{ }^{1} \mathrm{H}\right.$ COSY, TOCSY, and HMQC) of 1 (Fig. 1). The connectivities of $\mathrm{A}, \mathrm{B}$, and $\mathrm{C}$ and three quaternary methyls $(15-\mathrm{C}, 16-\mathrm{C}$, 17-C) through three quaternary carbons (1-C, 4-C, 8-C) were showed by elucidation of HMBC spectrum. Furthermore, the long-range correlations between $15-\mathrm{H}_{3}\left(\delta_{\mathrm{H}} 1.27\right)$ and 11-C $\left(\delta_{\mathrm{C}} 43.2\right)$, and between $20-\mathrm{H}_{3}\left(\delta_{\mathrm{H}} 1.72\right)$ and $12-\mathrm{C}\left(\delta_{\mathrm{C}} 53.6\right)$, $18-\mathrm{C}\left(\delta_{\mathrm{C}} 147.3\right)$, and $19-\mathrm{C}\left(\delta_{\mathrm{C}} 113.1\right)$ resulted in the formations of eleven- and five-membered rings composed of the $\mathrm{C}-\mathrm{C}$ bond between 1-C and 11-C, and the isopropenyl group attached to $12-\mathrm{C}$, respectively.

Meanwhile, the HMBC correlations were observed between $1^{\prime}-\mathrm{H}\left(\delta_{\mathrm{H}} 4.76\right)$ of the L-rhamnose unit in $\mathrm{D}$ and $2-\mathrm{C}$ $\left(\delta_{\mathrm{C}} 87.5\right)$, and $1^{\prime \prime}-\mathrm{H}\left(\delta_{\mathrm{H}} 4.48\right)$ of the L-arabinose unit in $\mathrm{E}$ and $4^{\prime}-\mathrm{C}\left(\delta_{\mathrm{C}} 84.6\right)$ (Fig. 1). The anomeric centers of the L-arabinose and L-rhamnose units were determined to be both $\alpha$ configuration in comparison with the ${ }^{13} \mathrm{C}$-NMR data of reference methyl glycosides. $\left.{ }^{2,3}\right)$ These data proved the sugar sequence as $2-O-\alpha$-L-arabinopyranosyl-( $1 \rightarrow 4)-\alpha$-L-rhamnopyranosyl. 
Table 1. ${ }^{1} \mathrm{H}$ - and ${ }^{13} \mathrm{C}-\mathrm{NMR}$ Data for $\mathbf{1}$ in Methanol- $d_{4}$

\begin{tabular}{|c|c|c|c|c|c|}
\hline & $\delta_{\mathrm{C}}$ & $\delta_{\mathrm{H}}$ & & $\delta_{\mathrm{C}}$ & $\delta_{\mathrm{H}}$ \\
\hline 1 & 51.7 & & & & rha \\
\hline 2 & 87.5 & $3.12(\mathrm{~d}, 9.2)$ & $1^{\prime}$ & 104.2 & 4.76 (brs) \\
\hline 3 & 68.4 & $2.88(\mathrm{~d}, 9.2)$ & $2^{\prime}$ & 72.9 & $3.90($ brd, 3.5$)$ \\
\hline 4 & 64.3 & & $3^{\prime}$ & 73.4 & $3.92(\mathrm{dd}, 3.5,8.6)$ \\
\hline \multirow[t]{2}{*}{5} & 40.6 & $1.25(\mathrm{dt}, 5.7,13.8)$ & $4^{\prime}$ & 84.6 & $3.55(\mathrm{dd}, 8.6,8.6)$ \\
\hline & & $2.11(\mathrm{ddd}, 2.9,4.6,13.8)$ & $5^{\prime}$ & 69.7 & $3.89(\mathrm{~m})$ \\
\hline \multirow[t]{2}{*}{6} & 25.4 & $2.16(\mathrm{~m})$ & $6^{\prime}$ & 18.9 & $1.30(\mathrm{~d}, 6.3)$ \\
\hline & & $2.43(\mathrm{~m})$ & & & ara \\
\hline 7 & 129.5 & $5.25(\mathrm{brd}, 11.5)$ & $1^{\prime \prime}$ & 107.4 & $4.48(\mathrm{~d}, 7.5)$ \\
\hline 8 & 138.3 & & $2^{\prime \prime}$ & 74.4 & $3.57(\mathrm{dd}, 7.5,8.6)$ \\
\hline 9 & 79.0 & $4.42(\mathrm{dd}, 5.7,11.5)$ & $3^{\prime \prime}$ & 75.4 & $3.52(\mathrm{dd}, 3.5,8.6)$ \\
\hline \multirow[t]{2}{*}{10} & 32.3 & $1.37(\mathrm{td}, 11.5,13.8)$ & $4^{\prime \prime}$ & 70.8 & 3.79 (brs) \\
\hline & & $1.58(\mathrm{br} d d, 5.8,13.8)$ & $5^{\prime \prime}$ & 68.4 & $3.54(\mathrm{brd}, 10.3)$ \\
\hline 11 & 43.2 & $1.65(\mathrm{br} \mathrm{dd}, 6.9,11.5)$ & & & $3.88(\mathrm{dd}, 2.3,11.0)$ \\
\hline 12 & 53.6 & $2.56(\mathrm{td}, 6.3,12.0)$ & & & \\
\hline \multirow[t]{2}{*}{13} & 28.7 & $1.55(\mathrm{~m})$ & & & \\
\hline & & 1.77 (br dt, $2.3,12.0)$ & & & \\
\hline \multirow[t]{2}{*}{14} & 39.1 & $1.39(\mathrm{~m})$ & & & \\
\hline & & $1.83(\mathrm{~m})$ & & & \\
\hline 15 & 21.7 & $1.27(\mathrm{~s})$ & & & \\
\hline 16 & 18.6 & $1.29(\mathrm{~s})$ & & & \\
\hline 17 & 11.6 & $1.57(\mathrm{~s})$ & & & \\
\hline 18 & 147.3 & & & & \\
\hline \multirow[t]{2}{*}{19} & 113.1 & 4.71 (brs) & & & \\
\hline & & 4.92 (brs) & & & \\
\hline 20 & 24.8 & $1.72(\mathrm{~s})$ & & & \\
\hline
\end{tabular}

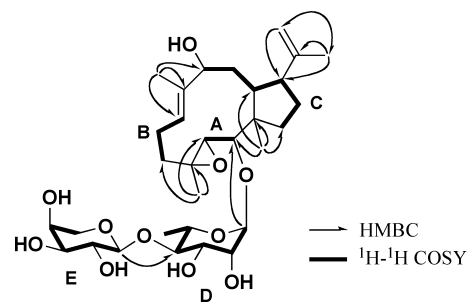

Fig. 1. ${ }^{1} \mathrm{H}-{ }^{1} \mathrm{H}$ COSY and HMBC Correlations of $\mathbf{1}$

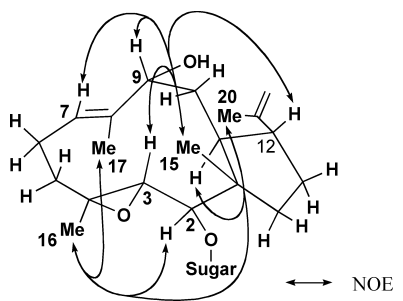

Fig. 2. NOE Correlations of $\mathbf{1}$

The relative stereochemistry of $\mathbf{1}$ was characterized by a nuclear Overhauser and exchange spectroscopy (NOESY) experiment, which showed nuclear Overhauser effect (NOE) correlations between the following proton pairs $(2-\mathrm{H}$ and $16-$ $\mathrm{H}_{3} ; 3-\mathrm{H}$ and $15-\mathrm{H}_{3} ; 7-\mathrm{H}$ and $15-\mathrm{H}_{3} ; 9-\mathrm{H}$ and $15-\mathrm{H}_{3} ; 11-\mathrm{H}$ and $20-\mathrm{H}_{3} ; 12-\mathrm{H}$ and $15-\mathrm{H}_{3} ; 16-\mathrm{H}_{3}$ and $17-\mathrm{H}_{3} ; 16-\mathrm{H}_{3}$ and $\left.20-\mathrm{H}_{3}\right)$ (Fig. 2). The NOESY spectrum revealed that $3-\mathrm{H}, 7-\mathrm{H}, 9-\mathrm{H}$, $12-\mathrm{H}$, and $15-\mathrm{H}_{3}$ were $\beta$-oriented, while $\mathrm{H}-2,11-\mathrm{H}, 16-\mathrm{H}_{3}$, $17-\mathrm{H}_{3}$, and the isopropenyl group linked to $12-\mathrm{C}$ were $\alpha$-oriented, and 7-C-8-C double bond had trans-geometry ( $E$ configuration). Therefore, the structure of $\mathbf{1}$ was elucidated to be $\left(1 R^{*}, 2 S^{*}, 3 S^{*}, 4 R^{*}, 7 E, 9 S^{*}, 11 R^{*}, 12 S^{*}\right)$-3,4-epoxy-dolabella-7,18-diene-2.9-diol 2- $O$ - $\alpha$-L-arabinopyranosyl-( $1 \rightarrow 4$ $\alpha$-L-rhamnopyranoside.
The molecular formula of squarroside $\mathrm{V}$ (2) was determined as $\mathrm{C}_{42} \mathrm{H}_{70} \mathrm{O}_{12}$ by the HR-ESI-MS showing a $\left[\mathrm{C}_{42} \mathrm{H}_{70} \mathrm{O}_{12} \mathrm{Na}\right]^{+}$ion at $\mathrm{m} / \mathrm{z}$ 789.4744. The ${ }^{1} \mathrm{H}-\mathrm{NMR}$ (pyridine- $d_{5}$ ) spectrum contained signals for a cyclopropane methylene proton at $\delta_{\mathrm{H}} 0.23(1 \mathrm{H}, \mathrm{d}, J=4.0 \mathrm{~Hz})$ and $0.48(1 \mathrm{H}$, d, $J=4.0 \mathrm{~Hz}$ ), four quaternary methyl protons at $\delta_{\mathrm{H}} 0.88$, $1.03,1.03$, and 1.31 , an olefinic methyl proton at $\delta 1.99$, two secondary methyl protons at $\delta_{\mathrm{H}} 1.15(\mathrm{~d}, J=6.9 \mathrm{~Hz})$ and 1.61 (d, $J=6.3 \mathrm{~Hz}$ ), two anomeric protons at $\delta_{\mathrm{H}} 4.72$ (d, $J=7.5 \mathrm{~Hz})$ and $5.16(\mathrm{~d}, J=7.5 \mathrm{~Hz})$, and an olefinic proton at $\delta_{\mathrm{H}} 5.65(1 \mathrm{H}, \mathrm{t}, J=7.5 \mathrm{~Hz})$. The ${ }^{1} \mathrm{H}-\mathrm{NMR}$ spectrum of 2 was similar to that of squarroside I. ${ }^{1)}$ The molecular formula of 2 was lower by $\mathrm{C}_{6} \mathrm{H}_{10} \mathrm{O}_{4}$ than that of squarroside I. In the ${ }^{13} \mathrm{C}$-NMR (pyridine- $d_{5}$ ) spectrum of $\mathbf{2}$, the chemical shifts showed coincidence with those of squarroside I, with the exception of the signals owing to the sugar moiety. On acid hydrolysis, 2 afforded D-fucose and D-glucose, together with several unidentified artificial sapogenols. The anomeric centers of the D-fucose and D-glucose units were determined to be both $\beta$-configurations from the ${ }^{3} J_{\mathrm{H} 1-\mathrm{H} 2}$ value. In the HMBC experiment, long-range correlations were observed between the anomeric proton $\left(\delta_{\mathrm{H}} 4.72\right)$ of 4 -substituted D-fucose unit and the $3-\mathrm{C}\left(\delta_{\mathrm{C}} 88.6\right)$, and the anomeric proton $\left(\delta_{\mathrm{H}}\right.$ $5.16)$ of terminal D-glucose unit and the $4^{\prime}-\mathrm{C}\left(\delta_{\mathrm{C}} 83.6\right)$ of 4 substituted D-fucose unit. These data proved the sugar sequence as $3-O-\beta$-D-glcopyranosyl-( $1 \rightarrow 4)$ - $\beta$-D-fucopyranosyl. From the above evidence, the structure of $\mathbf{2}$ was elucidated as a cycloartan glycoside with a rhamnose unit absent from squarroside I.

The molecular formula of squarroside VI (3) was higher by $\mathrm{C}_{6} \mathrm{H}_{10} \mathrm{O}_{5}$ than that of 2 . A comparative study of the ${ }^{1} \mathrm{H}$ NMR (pyridine- $d_{5}$ ) spectrum of $\mathbf{3}$ with that of $\mathbf{2}$ revealed them to be identical except for appearance of the new additional anomeric proton at $\delta_{\mathrm{H}} 5.08(\mathrm{~d}, J=8.1 \mathrm{~Hz})$. Meanwhile, a detailed comparison of the ${ }^{13} \mathrm{C}-\mathrm{NMR}$ (pyridine- $d_{5}$ ) spectrum of $\mathbf{3}$ with that of $\mathbf{2}$ showed the signal due to 6 "-C of glucose unit, which was shifted remarkably downfield by $7.5 \mathrm{ppm}$, and additional six carbon signals $\left(\delta_{\mathrm{C}} 105.4,78.2\right.$, 78.0, 75.0, 71.2, 62.5). On acid hydrolysis, 3 afforded D-fucose and D-glucose. The foregoing evidence indicated the presence of an additional glucose unit, which was linked to the hydroxy group at 6 "-C of the glucose unit, in 3. The anomeric proton signals at $\delta_{\mathrm{H}} 5.08\left(1^{\prime \prime \prime}-\mathrm{H}\right)$ showed longrange correlation with carbon signals at $\delta_{\mathrm{C}} 70.1\left(6^{\prime \prime}-\mathrm{C}\right)$ in the HMBC experiment. Conseqently, these data proved the sugar sequence as $3-O-\beta$-D-glucopyranosyl-( $(1 \rightarrow 6)-\beta$-D-glucopyranosyl-( $1 \rightarrow 4)$ - $\beta$-D-fucopyranosyl.

The HR-ESI-MS of squarroside VII (4) showed a peak at 1081.5912 corresponding to the molecular formula $\left[\mathrm{C}_{54} \mathrm{H}_{90} \mathrm{O}_{20} \mathrm{Na}\right]^{+}$(Calcd for 1081.5923). The ${ }^{1} \mathrm{H}-\mathrm{NMR}$ (pyridine- $d_{5}$ ) spectrum of $\mathbf{4}$ was similar to that of thalictoside C. ${ }^{4)}$ In the ${ }^{13} \mathrm{C}$-NMR (pyridine- $d_{5}$ ) spectrum of 4 , the chemical shifts showed coincidence with those of thalictoside $\mathrm{C}$ except for the signals owing to the terminal glucose unit, which was linked to the hydroxy group at 6-C of the inner glucose unit. On acid hydrolysis, 4 afforded D-fucose, D-glucose, Dquinovose, and L-rhamnose. The anomeric center of the Dquinovose unit was determined to be $\beta$-configuration from the ${ }^{3} J_{\mathrm{H} 1-\mathrm{H} 2}$ value. These data indicated the replacement of Dquinovose instead of D-glucose attached to the hydroxy group at $6-\mathrm{C}$ of the inner glucose unit in thalictoside $\mathrm{C}$. In the 
Table 2. ${ }^{1} \mathrm{H}$ - and ${ }^{13} \mathrm{C}-\mathrm{NMR}$ Data for $\mathbf{2 , 3}$, and $\mathbf{4}$ in Pyridine- $d_{5}$

\begin{tabular}{|c|c|c|c|c|c|c|}
\hline & \multicolumn{2}{|r|}{2} & \multicolumn{2}{|r|}{3} & \multicolumn{2}{|r|}{4} \\
\hline & $\delta_{\mathrm{C}}$ & $\delta_{\mathrm{H}}$ & $\delta_{\mathrm{C}}$ & $\delta_{\mathrm{H}}$ & $\delta_{\mathrm{C}}$ & $\delta_{\mathrm{H}}$ \\
\hline 1 & 32.1 & & 32.1 & & 32.2 & \\
\hline 2 & 29.9 & & 29.9 & & 29.9 & \\
\hline 3 & 88.6 & $3.45(\mathrm{dd}, 4.6,12.1)$ & 88.5 & $3.44(\mathrm{dd}, 4.6,12.0)$ & 89.2 & $3.42(\mathrm{dd}, 4.0,12.0)$ \\
\hline 4 & 41.2 & & 41.2 & & 41.2 & \\
\hline 5 & 47.9 & & 47.9 & & 47.9 & \\
\hline 6 & 21.0 & & 21.1 & & 21.1 & \\
\hline 7 & 26.1 & & 26.1 & & 26.1 & \\
\hline 8 & 47.5 & & 47.6 & & 47.6 & \\
\hline 9 & 20.0 & & 19.7 & & 20.0 & \\
\hline 10 & 26.2 & & 26.2 & & 26.2 & \\
\hline 11 & 26.6 & & 26.6 & & 26.2 & \\
\hline 12 & 33.3 & & 33.3 & & 33.3 & \\
\hline 13 & 45.3 & & 45.4 & & 45.4 & \\
\hline 14 & 49.0 & & 49.0 & & 49.0 & \\
\hline 15 & 35.7 & & 35.7 & & 35.8 & \\
\hline 16 & 27.9 & & 27.9 & & 27.9 & \\
\hline 17 & 49.0 & & 49.0 & & 49.0 & \\
\hline 18 & 18.2 & $1.03(\mathrm{~s})$ & 18.2 & $1.03(\mathrm{~s})$ & 18.2 & $1.01(\mathrm{~s})$ \\
\hline \multirow[t]{2}{*}{19} & 29.6 & $0.23(\mathrm{~d}, 4.0)$ & 29.6 & $0.24(\mathrm{~d}, 4.1)$ & 29.6 & $0.20(\mathrm{~d}, 4.1)$ \\
\hline & & $0.48(\mathrm{~d}, 4.0)$ & & $0.48(\mathrm{~d}, 4.1)$ & & $0.45(\mathrm{~d}, 4.1)$ \\
\hline 20 & 41.5 & & 41.5 & & 41.5 & \\
\hline 21 & 12.0 & $1.15(\mathrm{~d}, 6.9)$ & 12.0 & $1.15(\mathrm{~d}, 6.3)$ & 12.0 & $1.15(\mathrm{~s})$ \\
\hline 22 & 72.6 & $4.02(\mathrm{brs})$ & 72.7 & $4.03^{a)}$ & 72.7 & $4.02^{a)}$ \\
\hline 23 & 34.6 & & 34.6 & & 34.6 & \\
\hline 24 & 125.1 & $5.65(\mathrm{t}, 7.5)$ & 125.1 & $5.65(\mathrm{dd}, 6.9,7.5)$ & 125.2 & $5.65(\mathrm{dd}, 6.9,7.5)$ \\
\hline 25 & 137.4 & & 137.4 & & 137.4 & \\
\hline \multirow[t]{2}{*}{26} & 60.9 & $4.45(\mathrm{~d}, 12.1)$ & 60.9 & $4.45(\mathrm{~d}, 12.1)$ & 60.9 & $4.45(\mathrm{~d}, 12.1)$ \\
\hline & & $4.52(\mathrm{~d}, 12.1)$ & & $4.52(\mathrm{~d}, 12.1)$ & & $4.52(\mathrm{~d}, 12.1)$ \\
\hline 27 & 22.1 & $1.99(\mathrm{~s})$ & 22.1 & $2.00(\mathrm{~s})$ & 22.1 & $2.00(\mathrm{~s})$ \\
\hline 28 & 19.5 & $0.88(\mathrm{~s})$ & 19.5 & $0.89(\mathrm{~s})$ & 19.5 & $0.91(\mathrm{~s})$ \\
\hline 29 & 25.7 & $1.31(\mathrm{~s})$ & 25.7 & $1.31(\mathrm{~s})$ & 25.7 & $1.29(\mathrm{~s})$ \\
\hline 30 & 15.3 & $\begin{array}{l}1.03(\mathrm{~s}) \\
\text { fuc }\end{array}$ & 15.3 & $\begin{array}{l}1.02(\mathrm{~s}) \\
\text { fuc }\end{array}$ & 15.3 & $\begin{array}{l}1.00(\mathrm{~s}) \\
\text { fuc }\end{array}$ \\
\hline $1^{\prime}$ & 106.6 & $4.72(\mathrm{~d}, 7.5)$ & 106.7 & $4.69(\mathrm{~d}, 7.5)$ & 107.1 & $4.63(\mathrm{~d}, 7.5)$ \\
\hline $2^{\prime}$ & 73.1 & $4.33(\mathrm{dd}, 7.5,9.2)$ & 73.2 & $4.32(\mathrm{dd}, 7.5,9.2)$ & 72.7 & $4.44(\mathrm{dd}, 7.5,9.2)$ \\
\hline $3^{\prime}$ & 75.4 & 4.09 (dd, 3.5, 9.2) & 75.5 & $4.03(\mathrm{dd}, 3.2,9.2)$ & 75.5 & $4.03(\mathrm{dd}, 3.1,9.2)$ \\
\hline $4^{\prime}$ & 83.0 & $4.12(\mathrm{dd}, 1.1,3.5)$ & 82.6 & $4.09(\mathrm{dd}, 1.2,3.5)$ & 78.1 & $4.36(\mathrm{brd}, 2.9)$ \\
\hline $5^{\prime}$ & 70.3 & $3.78(\mathrm{dq}, 1.1,6.3)$ & 70.3 & $3.74(\mathrm{dq}, 1.2,6.3)$ & 70.5 & $3.73^{a)}$ \\
\hline $6^{\prime}$ & 17.6 & $\begin{array}{l}1.61(\mathrm{~d}, 6.3) \\
\mathrm{glc}\end{array}$ & 17.8 & $\begin{array}{l}1.70(\mathrm{~d}, 6.3) \\
\mathrm{glc}\end{array}$ & 18.0 & $\begin{array}{l}1.65(\mathrm{~d}, 6.3) \\
\mathrm{glc}\end{array}$ \\
\hline $1^{\prime \prime}$ & 106.8 & $5.16(\mathrm{~d}, 7.5)$ & 106.2 & $5.14(\mathrm{~d}, 8.0)$ & 103.2 & $5.43(\mathrm{~d}, 7.4)$ \\
\hline $2^{\prime \prime}$ & 75.9 & $4.00(\mathrm{dd}, 7.5,8.6)$ & 75.6 & $3.93(\mathrm{dd}, 8.0,8.6)$ & 78.4 & $4.10^{a)}$ \\
\hline $3^{\prime \prime}$ & 78.2 & $4.19(\mathrm{t}, 8.6)$ & 78.2 & $4.11(\mathrm{t}, 8.6)$ & 78.5 & $4.09(\mathrm{t}, 8.6)$ \\
\hline $4^{\prime \prime}$ & 71.4 & $4.16(t, 8.6)$ & 71.5 & $4.07(\mathrm{t}, 8.6)$ & 72.0 & $3.99(t, 8.6)$ \\
\hline $5^{\prime \prime}$ & 78.4 & $3.89(\mathrm{~m})$ & 77.3 & $3.99(\mathrm{~m})$ & 76.7 & $3.96(\mathrm{~m})$ \\
\hline \multirow{3}{*}{$6^{\prime \prime}$} & 62.6 & $4.31(\mathrm{dd}, 5.2,11.5)$ & 70.1 & $4.29(\mathrm{dd}, 5.7,11.5)$ & 70.1 & $4.19(\mathrm{dd}, 6.3,11.5)$ \\
\hline & & $4.47(\mathrm{dd}, 2.3,11.5)$ & & $4.74(\mathrm{dd}, 1.2,11.5)$ & & $4.74(\mathrm{dd}, 1.2,11.5)$ \\
\hline & & & & glc & & qui \\
\hline $1^{\prime \prime \prime}$ & & & 105.4 & $5.08(\mathrm{~d}, 8.1)$ & 105.1 & $4.96(\mathrm{~d}, 7.4)$ \\
\hline $2^{\prime \prime \prime}$ & & & 75.0 & $4.04(\mathrm{dd}, 8.1,8.6)$ & 75.1 & $4.01(\mathrm{dd}, 7.4,8.6)$ \\
\hline $3^{\prime \prime \prime}$ & & & 78.0 & $4.20(\mathrm{t}, 8.6)$ & 77.8 & $4.12(\mathrm{t}, 8.6)$ \\
\hline $4^{\prime \prime \prime}$ & & & 71.2 & $4.17(t, 8.6)$ & 76.5 & $3.69(t, 8.6)$ \\
\hline $5^{\prime \prime \prime}$ & & & 78.2 & $3.89(\mathrm{~m})$ & 72.9 & $3.73^{a)}$ \\
\hline \multirow[t]{3}{*}{$6^{\prime \prime \prime}$} & & & 62.5 & $4.30(\mathrm{dd}, 5.7,11.5)$ & 18.7 & $1.58(\mathrm{~d}, 5.7)$ \\
\hline & & & & $4.47(\mathrm{dd}, 2.3,11.5)$ & & \\
\hline & & & & & & rha \\
\hline $1^{\prime \prime \prime \prime}$ & & & & & 101.9 & $6.24(\mathrm{~d}, 1.8)$ \\
\hline $2^{\prime \prime \prime \prime}$ & & & & & 71.8 & $4.68(\mathrm{dd}, 1.8,3.5)$ \\
\hline $3^{\prime \prime \prime \prime}$ & & & & & 72.3 & $4.64(\mathrm{dd}, 3.5,9.2)$ \\
\hline $4^{\prime \prime \prime \prime}$ & & & & & 74.1 & $4.21(\mathrm{t}, 9.2)$ \\
\hline $5^{\prime \prime \prime \prime}$ & & & & & 70.1 & $4.84(\mathrm{~m})$ \\
\hline $6^{\prime \prime \prime \prime}$ & & & & & 18.6 & $1.72(\mathrm{~d}, 6.3)$ \\
\hline
\end{tabular}

a) Submerged by other signals. 
HMBC experiment, the anomeric proton signals at $\delta_{\mathrm{H}} 4.63$ (fuc 1'-H), 4.96 (qui 1'"'-H), 5.43 (glc 1"-H), and 6.24 (rha $\left.1^{\prime \prime \prime \prime}-\mathrm{H}\right)$ showed long-range correlations with the carbon signals at $\delta_{\mathrm{C}} 89.2$ (3-C), 70.1 (glc 6"-C), 78.1 (fuc 4'-C), and 78.4 (glc $2^{\prime \prime}-\mathrm{C}$ ), respectively. Thus, sugar sequence determined as $3-O-\beta$-D-quinovopyranosyl- $(1 \rightarrow 6)$ - $[\alpha$-L-rhamnopyranosyl- $(1 \rightarrow 2)]$ - $\beta$-D-glucopyranosyl- $(1 \rightarrow 4)$ - $\beta$-D-fucopyranosyl.

At the present time, the absolute configuration of squoside A (1) except for the sugar moiety has not yet been established. Although a number of dolabellane diterpenoids have been isolated from marine sources, this was the second report of dolabellane diterpene glycoside isolation from a higher plant. $^{5,6)}$

Meanwhile, in spite of the same ${ }^{1} \mathrm{H}-\mathrm{NMR}$ coupling pattern in D-fucopyranose units of $\mathbf{3}$ and $\mathbf{4}$, the ${ }^{13} \mathrm{C}$ signal due to fuc $4^{\prime}-\mathrm{C}\left(\delta_{\mathrm{C}} 78.1\right)$ in 4 was shifted to upfield by $4.5 \mathrm{ppm}$, as compared with fuc $4^{\prime}-\mathrm{C}\left(\delta_{\mathrm{C}} 82.6\right)$ in 3 . This upfield shift suggested to be caused by L-rhamnopyranosyl group attached to glc $2^{\prime \prime}-\mathrm{C}$. The strange shift pattern was observed in thalictoside $\mathrm{C}$. ${ }^{4)}$

\section{Experimental}

General Procedure Optical rotations were taken with a JASCO DIP1000 automatic digital polarimeter. Both ${ }^{1} \mathrm{H}$ - and ${ }^{13} \mathrm{C}$-NMR spectra were recorded in methanol- $d_{4}$ and pyridine- $d_{5}$ solutions on a JEOL ECA 500 $(500,125 \mathrm{MHz}$, respectively) spectrometer. The chemical shifts $(\delta)$ are reported in parts per million (ppm) and $J$ values in $\mathrm{Hz}$, using pyridine- $d_{5}$ for ${ }^{1} \mathrm{H}-\mathrm{NMR}(7.20 \mathrm{ppm})$ and ${ }^{13} \mathrm{C}-\mathrm{NMR}(123.5 \mathrm{ppm})$, and methanol- $d_{4}$ for ${ }^{1} \mathrm{H}-$ NMR (3.30 ppm) and ${ }^{13} \mathrm{C}-\mathrm{NMR}(49.0 \mathrm{ppm})$ as an internal standard. The HRESI-MS was recorded with a JEOL JMS-T100LP spectrometer. HPLC was carried out using the Mightysil RP-18 (10.0 mm i.d. $\times 250 \mathrm{~mm}$, Kanto Chemical Co., Ltd., Tokyo, Japan) column with a Tosoh CCPM pump, Tosoh RI8010 detector, and JASCO OR-2090 detector. TLC was performed on precoated silica gel $60 \mathrm{~F}_{254}$ (Merck Ltd., Tokyo, Japan), and detection was achieved by spraying with $10 \% \mathrm{H}_{2} \mathrm{SO}_{4}$ followed by heating. Column chromatography was carried out on silica gel 60 (230 - 400 mesh, Merck Ltd., Tokyo, Japan), Sephadex-LH20 (Pharmacia Fine Chemicals), ODS (Bondapak $\mathrm{C}_{18}$ Cartridge $15-20 \mathrm{~mm}$, Waters Corp.), and MCI gel CHP20P (Mitsubishi Chemical Ind.)

Plant Material The fresh aerial parts of Thalictrum squarrosum SтерH. were collected in Heilungkiang province of China. A voucher specimen was deposited in the Herbarium of Kumamoto University.

Extraction and Isolation The dried aerial parts of Thalictrum squarrosum $(4.1 \mathrm{~kg})$ was extracted with hot methanol. The $\mathrm{MeOH}$ extract $(511 \mathrm{~g})$ was partitioned between water-soluble $(402 \mathrm{~g})$ and benzene-soluble $(109 \mathrm{~g})$ portions. The water-soluble portion subjected to MCI gel CHP20P $\left[\mathrm{MeOH}-\mathrm{H}_{2} \mathrm{O} \quad(30: 70 \rightarrow 40: 60 \rightarrow 50: 50 \rightarrow 60: 40 \rightarrow 70: 30 \rightarrow 80: 20 \rightarrow 90: 10\right.$ $\mathrm{v} / \mathrm{v}) \rightarrow \mathrm{MeOH}$ ] column chromatography to afford four fractions [Fractions 1 $(14.5 \mathrm{~g}), 2(6.5 \mathrm{~g}), 3(7.3 \mathrm{~g})$, and $4(2.7 \mathrm{~g})]$. Fraction $1(14.5 \mathrm{~g})$ was further separated by ODS $\left[\mathrm{MeOH}-\mathrm{H}_{2} \mathrm{O}(40: 60 \rightarrow 50: 50 \rightarrow 60: 40, \mathrm{v} / \mathrm{v})\right]$ and silica gel $\left[\mathrm{CHCl}_{3}-\mathrm{MeOH}-\mathrm{H}_{2} \mathrm{O}(8: 2: 0.2, \mathrm{v} / \mathrm{v} / \mathrm{v})\right]$ column chromatographies, followed by HPLC $\left[\mathrm{MeOH}-\mathrm{H}_{2} \mathrm{O}(60: 40, \mathrm{v} / \mathrm{v})\right]$ to furnish squoside A (1,
$14 \mathrm{mg})$. Fraction $4(2.7 \mathrm{~g})$ subjected to ODS [MeOH- $\mathrm{H}_{2} \mathrm{O}(70: 30 \rightarrow$ $80: 20 \rightarrow 90: 10, \mathrm{v} / \mathrm{v}$ )] column chromatography to afford five fractions [Fractions $5(393 \mathrm{mg}), 6(165 \mathrm{mg}), 7(124 \mathrm{mg}), 8(187 \mathrm{mg})$, and $9(129 \mathrm{mg})]$. Fraction 6 was further separated by Sephadex-LH20 $[\mathrm{MeOH}]$ and silica gel $\left[\mathrm{CHCl}_{3}-\mathrm{MeOH}-\mathrm{H}_{2} \mathrm{O}(7: 3: 0.5, \mathrm{v} / \mathrm{v} / \mathrm{v})\right]$ column chromatographies, followed by HPLC $\left[\mathrm{MeOH}-\mathrm{H}_{2} \mathrm{O}(85: 15, \mathrm{v} / \mathrm{v})\right]$ to furnish squarrosides VII $(4,19 \mathrm{mg})$. Fraction 7 was further separated by silica gel $\left[\mathrm{CHCl}_{3}-\mathrm{MeOH}-\mathrm{H}_{2} \mathrm{O}\right.$ $(7: 3: 0.5, \mathrm{v} / \mathrm{v} / \mathrm{v})]$ column chromatography, followed by HPLC $\left[\mathrm{MeOH}-\mathrm{H}_{2} \mathrm{O}\right.$ $(85: 15, \mathrm{v} / \mathrm{v})]$ to furnish squarrosides VI $(3,10 \mathrm{mg})$. Fraction 8 was further separated by Sephadex-LH20 $[\mathrm{MeOH}]$ and silica gel $\left[\mathrm{CHCl}_{3}-\mathrm{MeOH}-\mathrm{H}_{2} \mathrm{O}\right.$ $(7: 3: 0.5, \mathrm{v} / \mathrm{v} / \mathrm{v})]$ column chromatographies, followed by HPLC $[\mathrm{MeOH}-$ $\left.\mathrm{H}_{2} \mathrm{O}(85: 15, \mathrm{v} / \mathrm{v})\right]$ to furnish squarrosides $\mathrm{V}(2,8 \mathrm{mg})$.

Squoside A (1): Amorphous powder; $[\alpha]_{\mathrm{D}}-27.4^{\circ}(c=0.71, \mathrm{MeOH})$; HRESI-MS m/z $621.3238[\mathrm{M}+\mathrm{Na}]^{+}$; (Calcd for $\left.\mathrm{C}_{31} \mathrm{H}_{50} \mathrm{O}_{11} \mathrm{Na}, 621.3251\right) ;{ }^{1} \mathrm{H}-$ and ${ }^{13} \mathrm{C}$-NMR data (Table 1 ).

Squarroside V (2): Amorphous powder; $[\alpha]_{\mathrm{D}}+17.0^{\circ}(c=0.38, \mathrm{MeOH})$; HR-ESI-MS $m / z 789.4744[\mathrm{M}+\mathrm{Na}]^{+}$; (Calcd for $\left.\mathrm{C}_{42} \mathrm{H}_{70} \mathrm{O}_{12} \mathrm{Na}, 789.4765\right)$; ${ }^{1} \mathrm{H}$ - and ${ }^{13} \mathrm{C}-\mathrm{NMR}$ data (Table 2).

Squarroside VI (3): Amorphous powder; $[\alpha]_{\mathrm{D}}+5.3^{\circ}(c=0.50, \mathrm{MeOH})$; HR-ESI-MS $m / z$ 951.5271 [M+Na] $]^{+}$; (Calcd for $\left.\mathrm{C}_{48} \mathrm{H}_{80} \mathrm{O}_{17} \mathrm{Na}, 951.5293\right)$; ${ }^{1} \mathrm{H}-$ and ${ }^{13} \mathrm{C}-\mathrm{NMR}$ data (Table 2).

Squarroside VII (4): Amorphous powder; $[\alpha]_{\mathrm{D}}-17.9^{\circ}(c=0.94, \mathrm{MeOH})$; HR-ESI-MS $m / z \quad 1081.5912 \quad[\mathrm{M}+\mathrm{Na}]^{+} ;$(Calcd for $\mathrm{C}_{54} \mathrm{H}_{90} \mathrm{O}_{20} \mathrm{Na}$, 1081.5923); ${ }^{1} \mathrm{H}$ - and ${ }^{13} \mathrm{C}-\mathrm{NMR}$ data (Table 2).

Sugar Analysis A solution of each compound $(\mathbf{1}, \mathbf{2}, \mathbf{3}$, or 4$)(1.0 \mathrm{mg})$ in $2 \mathrm{M} \mathrm{HCl} /$ dioxane $(1: 1,2 \mathrm{ml})$ was heated at $100^{\circ} \mathrm{C}$ for $1 \mathrm{~h}$. The reaction mixture was diluted with $\mathrm{H}_{2} \mathrm{O}$ and evaporated to remove dioxane. The solution was neutralized with Amberlite MB-3 and passed through a SEP-PAK $\mathrm{C}_{18}$ cartridge to give a sugar fraction. The sugar fraction was concentrated to dryness in vacuo to give a residue, which was dissolved in $\mathrm{CH}_{3} \mathrm{CN} / \mathrm{H}_{2} \mathrm{O}$ $(3: 1,250 \mu 1)$. The sugar fraction was analyzed by HPLC under the following conditions: column, Shodex RS-Pak DC-613 $(6.0 \mathrm{~mm}$ i.d. $\times 150 \mathrm{~mm}$, Showa Denko, Tokyo, Japan); solvent, $\mathrm{CH}_{3} \mathrm{CN} / \mathrm{H}_{2} \mathrm{O}$ (3:1); flow rate, $1.0 \mathrm{ml} / \mathrm{min}$; column temperature, $70^{\circ} \mathrm{C}$; detection, optical rotation (OR). The $t_{\mathrm{R}}(\mathrm{min})$ of the sugars was as follows. 1: L-rhamnose $4.7(-)$, L-arabinose 6.2 $(+), 2$ : D-fucose $4.6(+)$, D-glucose $7.2(+), 3$ : D-fucose $4.6(+)$, D-glucose $7.2(+), 4$ : D-fucose $4.6(+)$, D-quinovose $4.9(+)$, D-glucose $7.2(+)$. [Reference: D-fucose 4.6 (positive optical rotation: + ), L-rhamnose 4.7 (negative optical rotation: -), D-quinovose 4.9 (positive optical rotation: + ), L-arabinose 6.2 (positive optical rotation: + ), D-glucose 7.4 (positive optical rotation: +$)]$

\section{References}

1) Yoshimitsu H., Nishida M., Qian Z.-Z. M., Lei Z.-H., Nohara T., Chem. Pharm. Bull., 48, 828-831 (2000).

2) Seo S., Tomita Y., Tori K., Yoshimura Y., J. Am. Chem. Soc., 24, $3331-3339$ (1978)

3) Mizutani, K., Kasai, R., Tanaka O., Carbohydr. Res., 87, 19-26 (1980).

4) Yoshimitsu H., Hayashi K., Shingu K., Kinjo J., Yahara S., Nakano K., Murakami K., Tomimatsu T., Nohara T., Chem. Pharm. Bull., 40, $2465-2468$ (1992)

5) Rodriguez A. D., Gonzalez E., Ramirez C., Tetrahedron, 54, 1168311729 (1998).

6) Mohamed K. M., Ohtani K., Kasai R., Yamasaki K., Phtytochemistry, 37, 495-500 (1994). 